\title{
Biocompatibility of Portland cement combined with different radiopacifying agents
}

\author{
Natalino Lourenço Neto1), Nádia C. T. Marques'1), Ana Paula Fernandes1), \\ Camila O. Rodini2), Marco A. H. Duarte'), Marta C. Lima'), \\ Maria A. A. M. Machado1), Ruy C. C. Abdo'1), and Thais M. Oliveira1) \\ 1)Department of Pediatric Dentistry, Orthodontics and Public Health, Bauru School of Dentistry, \\ University of São Paulo, Bauru, SP, Brazil \\ 2)Department of Biology Science, Bauru School of Dentistry, University of São Paulo, Bauru, SP, Brazil \\ 3)Department of Operative Dentistry, Endodontic and Dental, Bauru School of Dentistry, \\ University of São Paulo, Bauru, SP, Brazil \\ 4)Matrix Dynamics Group, Faculty of Dentistry, University of Toronto, Toronto, Canada
}

(Received September 9, 2013; Accepted January 9, 2014)

\begin{abstract}
The aim of this study was to evaluate the response of rat subcutaneous tissue to Portland cement combined with two different radiopacifying agents, iodoform $\left(\mathrm{CHI}_{3}\right)$ and zirconium oxide $\left(\mathrm{ZrO}_{2}\right)$. These materials were placed in polyethylene tubes and implanted into the dorsal connective tissue of Wistar rats for 7 and 15 days. The specimens were then stained with hematoxylin and eosin, and inflammatory reaction parameters were evaluated by light microscopy. The intensity of the inflammatory response to the sealants was analyzed by two blind calibrated observers throughout the experimental period. Histological analysis showed that all the materials caused a moderated inflammatory reaction at 7 days, which then diminished with time. At 15 days, the inflammatory reaction was almost absent, and fibroblasts and collagen fibers were observed indicating normal tissue healing. The degrees of the inflammatory reaction on different days throughout the experimental period were compared using the non-parametric Kruskal-Wallis test. Statistical analysis
\end{abstract}

Correspondence to Dr. Thais Marchini Oliveira, Bauru School of Dentistry, University of São Paulo, Alameda Dr. Octávio Pinheiro Brisolla, 9-75, Bauru, São Paulo 17012-901, Brazil

Email: marchini@usp.br

doi.org/10.2334/josnusd.56.29

DN/JST.JSTAGE/josnusd/56.29 demonstrated no significant differences amongst the groups, and Portland cement associated with radiopacifying agents gave satisfactory results. Therefore, Portland cement used in combination with radiopacifying agents can be considered a biocompatible material. Although our results are very encouraging, further studies are needed in order to establish safe clinical indications for Portland cement combined with radiopacifying agents.

(J Oral Sci 56, 29-34, 2014)

Keywords: biocompatibility; Portland cement; radiopacifying; endodontics; subcutaneous implant; materials testing.

\section{Introduction}

Biocompatibility is an important requirement for dental materials, as any toxic components may induce irritation or even degeneration of the surrounding tissues $(1,2)$. Therefore, the biocompatibility of all dental materials that could potentially come in contact with tissues should be investigated (1). This property is of special significance for endodontic materials $(3,4)$ because sealants may cause different reactions in the dental pulp (4-7). Subcutaneous tissue reaction is one of the in vivo biocompatibility tests that have been used for evaluating several new materials $(2,8-10)$. 
Portland cement is the main component of mineral trioxide aggregate (MTA), but bismuth oxide at a 4:1 ratio is added to MTA to provide radiopacity (11). Portland cement (PC) has emerged as an alternative to MTA because of its relative lower cost, similar chemical composition and biocompatibility with MTA, and several studies have compared both materials (12-16). As PC may potentially be used as an endodontic material $(11,17)$, it does not have sufficient radiopacity to be visualized radiographically, and therefore a radiopacifying agent must be added to it (11).

A number of studies have testing new combinations of $\mathrm{PC}$ with different radiopacifying agents, and zirconium oxide in particular has demonstrated excellent results, as it is biocompatible and does not interfere with the properties of PC $(11,18,19)$. Another tested radiopacifying agent is iodoform, which has been used successfully in dentistry and research for many years, showing both antibacterial properties and biocompatibility (20).

Therefore, the aim of this study was to evaluate the response of rat subcutaneous tissue to Portland cement combined with two different radiopacifying agents, iodoform $\left(\mathrm{CHI}_{3}\right)$ and zirconium oxide $\left(\mathrm{ZrO}_{2}\right)$.

\section{Materials and Methods}

The Ethics Committee of Bauru School of Dentistry, University of São Paulo, approved the protocol for this study (\#025/2010).

Twelve male rats weighing 200-250 g, from the Central Animal Laboratory of Bauru Dental School, were randomly distributed into three groups: Group I - Portland cement (PC) $(n=4)$; Group II - Portland cement added to iodoform $\left(\mathrm{PC}+\mathrm{CHI}_{3}\right)(n=4)$; Group III - Portland cement added to zirconium oxide ( $\mathrm{PC}+$ $\left.\mathrm{ZrO}_{2}\right)(n=4)$.

Thirty-six polyethylene tubes (Abbott Labs of Brazil, São Paulo, Brazil) with an internal diameter of $1.0 \mathrm{~mm}$, external diameter of $1.6 \mathrm{~mm}$, and length of $10.0 \mathrm{~mm}$ were disinfected in 5\% sodium hypochlorite for 1 hour, washed in saline solution for $15 \mathrm{~min}$, dried with sterile gauze, then filled with the materials to be tested. Three tubes were used in each animal. All the cements used were based on pure white PC (Votorantim-Cimentos, São Paulo, SP, Brazil) with addition of different radiopacifying agents. A ratio of $20 \%$ radiopacifier and $80 \%$ white $\mathrm{PC}$ by weight was used to fill the tubes (11). The radiopacifying agents and PCs were prepared in sterilized glass plaque, using as the measure parameter the MTA kit spoon for the powder ( $1 \mathrm{~g}$ cement powder) and two drops of distilled water (0.3 mL liquid), obtaining a paste of the material (21). The tubes were filled with the tested material previous to subcutaneous implantation.

The animals were anesthetized with an intramuscular injection of a mixture of ketamine (Dopalen)/xilazine (Anasedan) at $0.4 \mathrm{~mL} / 0.02 \mathrm{~mL} / \mathrm{kg}$ body weight. The dorsal skin was shaved, disinfected with $5 \%$ tincture of iodine, and two small parallel incisions (anterior and posterior), approximately $1.5 \mathrm{~cm}$ long, were made with a scalpel. Two separated pockets were created by blunt dissection, one in the cranial portion, used for housing one tube and, another in the caudal portion, housing two tubes, one on each side, for implantation of the tubes in the subcutaneous tissue. The tubes containing freshly mixed sealants were then placed into the pockets, taking care to prevent any spillage of the material into the tissue. After implantation, the wounds were sutured and the animals did not receive antibiotics and/or analgesics.

Six animals were sacrificed by an overdose of anesthetics at both 7 and 15 days after the operation. The tubes were excised together with the surrounding skin and connective tissue. The samples were immersed for $48 \mathrm{~h}$ in buffered $10 \%$ formalin $(0.1 \mathrm{~mol} / \mathrm{L}$ solution), and then subjected to histological processing. The specimens were dehydrated in an ascending series of ethanol rinses, the blocks were embedded in paraffin, and tissue sections $5 \mu \mathrm{m}$ thick were cut and stained with hematoxylin and eosin.

Histologic sections of the sealant-connective tissue interface (at the open ends of the tubes) were analyzed by light microscopy for inflammatory tissue reactions. The connective tissue response adjacent to the outer lateral wall of the tube served as a negative control.

The observers were blinded to the materials used in the specimens. The overall mean value of the inflammatory reaction for each material was determined for each rat at each time point. Evaluation was performed according to a modified version of the Coutinho-Filho et al. (22) criteria. The degree of inflammation was determined according to the type, number and concentration of the predominant cells. The presence or absence of neutrophils, inflammatory infiltrates, giant cells, and macrophages was recorded. For each of these elements, the following numerical scores were assigned: grade 0 , none (without inflammatory cells); grade 1, mild (inflammatory cells present in small numbers or in small groups); grade 2, moderate (inflammatory cells in large numbers, yet not predominantly in the microscopic field); grade 3 , intense (inflammatory infiltrate, predominantly in the microscopic field); grade 4, necrosis. The Kruskal-Wallis test was used for statistical analysis, and the level of statistical significance was defined as $P<0.05$. 
Table 1 Histological evaluation of tested materials at 7 and 15 days (values as scores)

\begin{tabular}{lcc}
\hline & \multicolumn{2}{c}{ Scores } \\
\hline Specimens & 7 days & 15 days \\
\hline $\mathrm{PC}-1 \mathrm{~A}$ & 1 & 2 \\
$\mathrm{PC}-1 \mathrm{~B}$ & 3 & 1 \\
$\mathrm{PC}-1 \mathrm{C}$ & 1 & 1 \\
$\mathrm{PC}-2 \mathrm{~A}$ & 2 & 2 \\
$\mathrm{PC}-2 \mathrm{~B}$ & 2 & 1 \\
$\mathrm{PC}-2 \mathrm{C}$ & 3 & 2 \\
$\mathrm{PC}+\mathrm{CHI}_{3}-1 \mathrm{~A}$ & 1 & 0 \\
$\mathrm{PC}+\mathrm{CHI}_{3}-1 \mathrm{~B}$ & 0 & 0 \\
$\mathrm{PC}+\mathrm{CHI}_{3}-1 \mathrm{C}$ & 1 & 0 \\
$\mathrm{PC}+\mathrm{CHI}_{3}-2 \mathrm{~A}$ & 1 & 1 \\
$\mathrm{PC}+\mathrm{CHI}_{3}-2 \mathrm{~B}$ & 2 & 2 \\
$\mathrm{PC}+\mathrm{CHI}_{3}-2 \mathrm{C}$ & 1 & 1 \\
$\mathrm{PC}+\mathrm{ZrO}_{2}-1 \mathrm{~A}$ & 2 & 1 \\
$\mathrm{PC}+\mathrm{ZrO}_{2}-1 \mathrm{~B}$ & 1 & 1 \\
$\mathrm{PC}+\mathrm{ZrO}_{2}-1 \mathrm{C}$ & 1 & 1 \\
$\mathrm{PC}+\mathrm{ZrO}_{2}-2 \mathrm{~A}$ & 1 & 1 \\
$\mathrm{PC}+\mathrm{ZrO}_{2}-2 \mathrm{~B}$ & 2 & 1 \\
$\mathrm{PC}+\mathrm{ZrO}_{2}-2 \mathrm{C}$ & 2 & 1 \\
\hline
\end{tabular}

\section{Results}

Two blinded and previously calibrated observers analyzed the intensity of the inflammatory response in the connective tissue around the sealants during the experimental period (kappa 0.96). The connective tissue response adjacent to the outer lateral wall of the tube was evaluated as a negative control, and showed no inflammatory reaction at any time point. Histological evaluation showed that all the materials caused a moderate inflammatory reaction at 7 days, which had decreased by 15 days (Table 1 ).

At 7 days, $66.7 \%$ of the specimens from the PC group demonstrated grade 2 to 3 inflammation characterized by the presence of large numbers of inflammatory cells. The bulk of the remaining material and giant cells were also observed in most cases (Fig. 1). At 15 days this percentage $(66.7 \%)$ corresponded to that of specimens demonstrating grade 1 inflammation, in accordance with the tissue repair that had occurred during this period (Fig. 2).

After 7 days, $66.7 \%$ of the specimens from the PC + $\mathrm{CHI}_{3}$ group was classified as having grade 1 inflammation, presenting sporadic inflammatory cells associated with remnants of the material in some cases (Fig. 3). At 15 days, $83.4 \%$ of the specimens were graded as 0 to 1 , with nearly no tissue inflammation and the presence of collagen fibers, indicating normal tissue healing (Fig. 4).

In the $\mathrm{PC}+\mathrm{ZrO}_{2}$ group, $50 \%$ of the specimens demonstrated grade 2 inflammation at 7 days, inflammatory cells

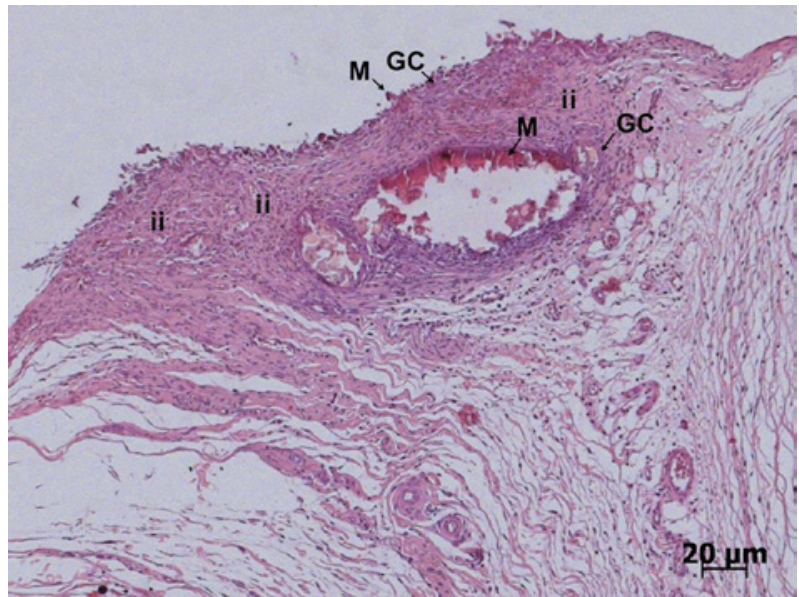

Fig. 1 At 7 days, Portland cement (Group I) was associated with moderate to intense inflammation, with the presence of a large number of inflammatory cells (ii). The bulk of the remaining material $(\mathrm{M})$ and giant cells $(\mathrm{GC})$ are also observed.

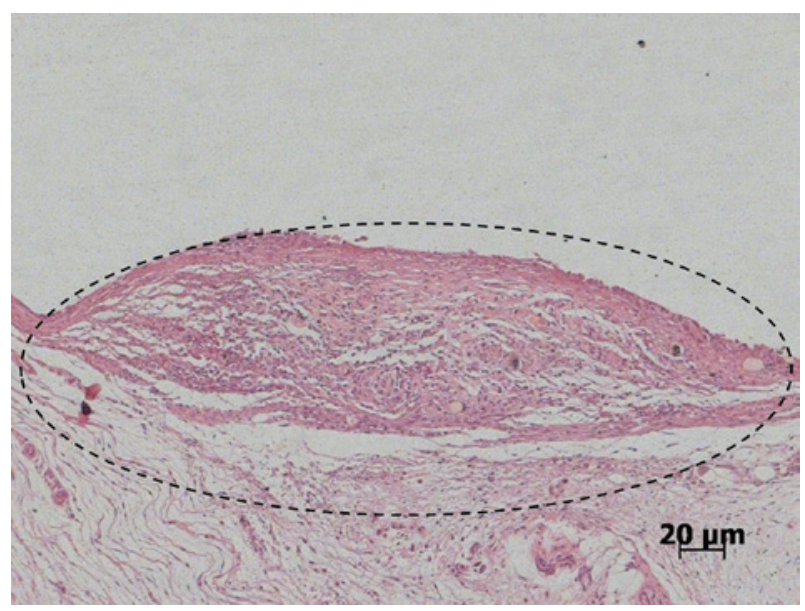

Fig. 2 At 15 days, Portland cement (Group I) was associated with fibroblasts and collagen fibers, indicating normal tissue healing.

being associated with the remaining material (Fig. 5). At 15 days, $83.4 \%$ of the specimens had grade 1 inflammation, and the presence of fibroblasts and collagen fibers indicated normal tissue healing (Fig. 6).

The Kruskal-Wallis test demonstrated no statistically significant differences among the PC groups and the other tested groups $(P>0.05)$. However, morphological analysis revealed a lower prevalence of inflammation in specimens that included radiopacifying agents.

\section{Discussion}

Implantation of new endodontic materials into subcutaneous tissues of rats is one of the most suitable methods for determining their local effects and biocompatibility $(2,9,10,22-24)$. As well as preliminary tests for materials that are utilized for root-end filling, furcal perforation, 


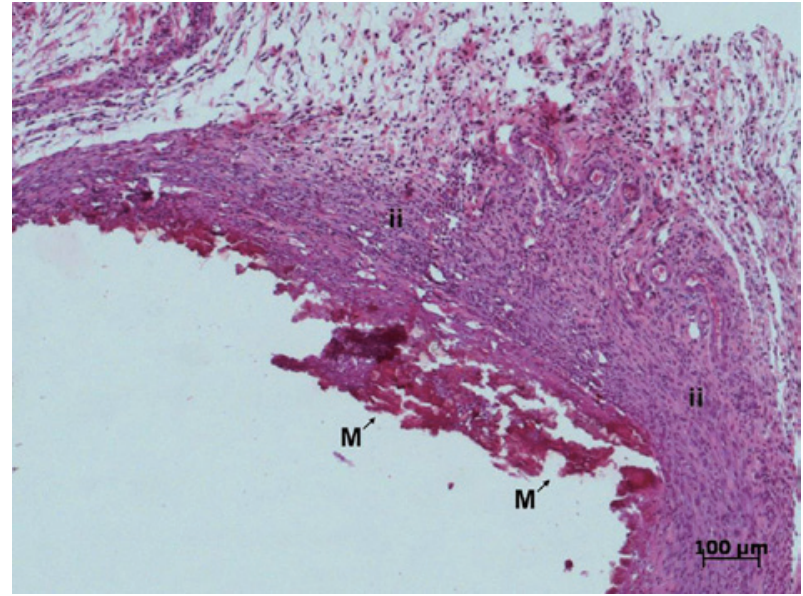

Fig. 3 At 7 days, Portland cement mixed with iodoform (Group II) was associated with sporadic inflammatory cells (ii) and remnants of the material (M) in some cases.

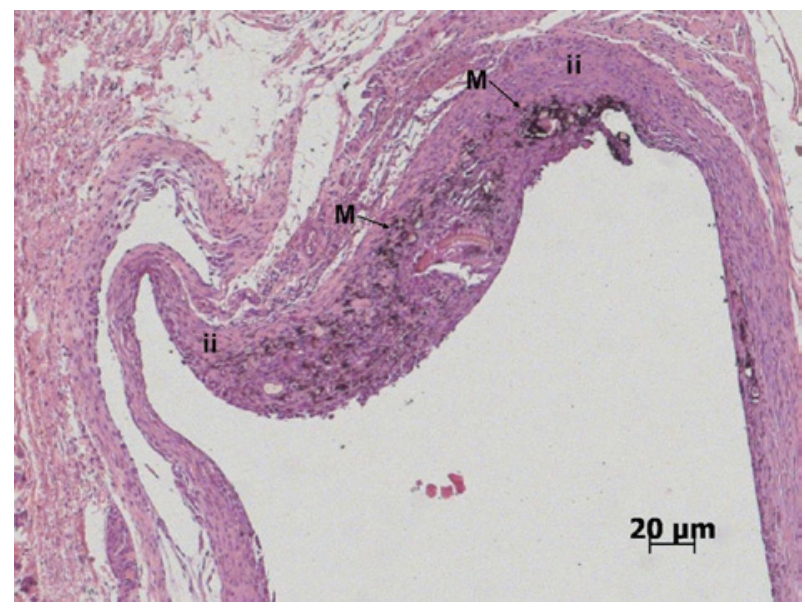

Fig. 5 At 7 days, Portland cement mixed with zirconium oxide (Group III) showed moderate associated inflammation with the presence of inflammatory cells (ii), adjacent to remaining material $(\mathrm{M})$.

and as apical barriers, such materials must be investigated for their biocompatibility characteristics, as toxic components present in them might induce irritation or even degeneration of the surrounding tissues, especially is they are accidentally extruded into the periradicular tissues $(4,25)$.

Portland cement and MTA have similar major constituents, except for bismuth oxide, which is added to MTA to provide radiopacity $(11,26,27)$. Although this feature does not compromise the execution of pulpotomy procedures with PC and their follow-up assessments, this property is necessary in order to distinguish the material from surrounding anatomical structures such as tooth and bone $(11,17,18,28)$, and to permit the material to achieve the minimum values recommended by the American National Standards Institute / American Dental Associa-

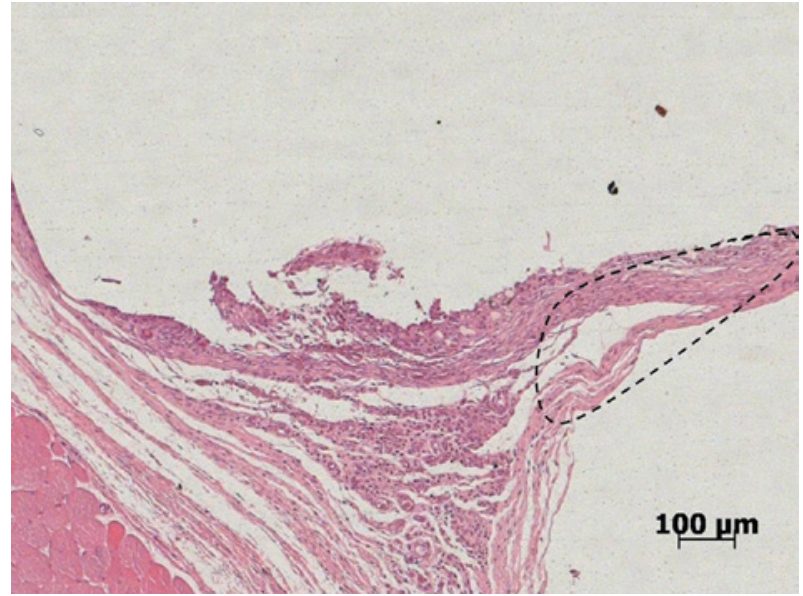

Fig. 4 At 15 days, Portland cement mixed with iodoform (Group II) showed nearly no tissue inflammation and the presence of collagen fibers, indicating normal tissue healing.

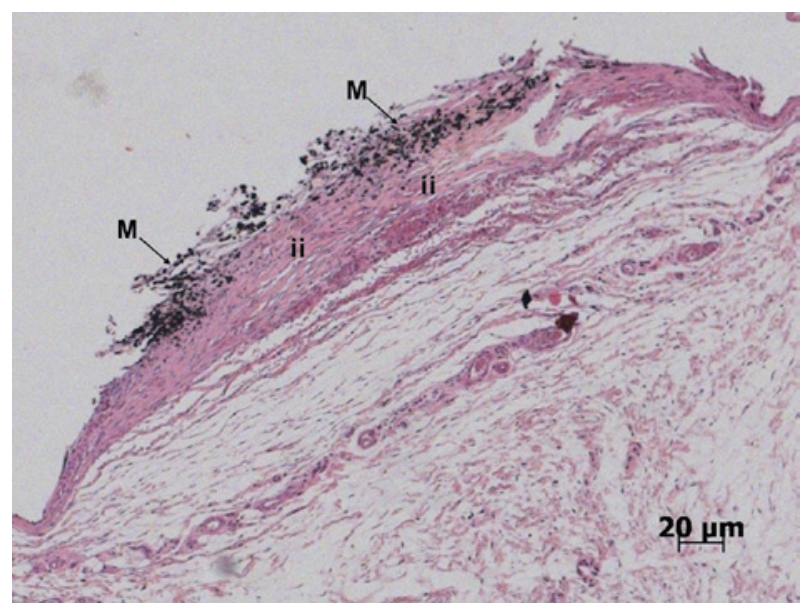

Fig. 6 After 15 days, Portland cement mixed with zirconium oxide (Group III) showed remaining material (M), mild inflammation (ii), and the presence of fibroblasts and collagen fibers, indicating normal tissue healing.

tion (ANSI/ADA) standard No 57/2000 (29).

The ideal radiopacifying material should only present the necessary radiopacity for the cement and should be inert, free from any contaminants, non-toxic and added in minimal amounts $(11,18)$. Húngaro-Duarte et al. (11), Coomaraswamy et al. (27) and de Morais et al. (30) showed that addition of bismuth oxide to PC dramatically changed the material constants; these results have stimulated the search for an alternative radiopacifying agent for use with PC. Addition of other radiopacifying agents such as zirconium oxide and iodoform results in a cement with greater radiopacity than dentin, and both of these agents are present in the formulations of several other endodontic sealants. Recent studies have shown that zirconium oxide does not interfere with the properties of PC such as calcium ion release, solubility and 
setting time, thus allowing PC to retain its strength and sealing properties. Addition of these two radiopacifying agents also does not change the $\mathrm{pH}$, thus maintaining the alkalinization ability of $\mathrm{PC}$, which is important for maintaining the antimicrobial activity of the cement (21).

The present results are in agreement with those of previous studies, suggesting that these radiopacifying agents do not cause adverse effects $(11,20)$. The iodoform was tested as a radiopacifier for addition to Portland cement because of its satisfactory radiopacity, its widespread availability to clinicians, and earlier reports indicating that it is harmless to pulp and periapical tissues $(28,30)$. The zirconium oxide, a bioinert material with good biocompatibility, has been confirmed to have good biocompatibility and no cytotoxic effects on fibroblasts (20,31). Gomes Cornélio et al. (20) showed that Portland cement associated with zirconium oxide is not cytotoxic to periodontal ligament cells and might be a good alternative as a radiopacifying agent. Therefore, the addition of radiopacifying agents such as zirconia and iodoform as capping materials may be considered, since they allowed satisfactory tissue repair throughout the observation period.

In this investigation, histological evaluation showed that all tested materials had caused an inflammatory reaction at 7 days, and that this then decreased with time. Although there were no significant differences among the groups, morphological analysis revealed that there was less inflammation in specimens that included radiopacifying agents. In general, the cellular events and inflammatory responses observed in the present study were similar in the experimental groups. Therefore, the present results indicate that these radiopacifying agents are biocompatible, and provide preliminary data for their potential use with Portland cement in various dental applications. Although our results are very encouraging, further research in vitro and in vivo will be needed to assess the biological effects of these radiopacifying agents with Portland cement, including their inflammatory and regenerative properties. Additional high-quality randomized control trials will be needed to analyse and appraise the long-term effects of these agents.

\section{Acknowledgments}

The authors would like to acknowledge the financial support of The São Paulo Research Foundation (FAPESP Grants \#2009/11284-4 to TMO). The authors would like to thank Daniele Santi Ceolin and Patrícia De Sá Mortágua Gemino for their excellent laboratory assistance.

\section{References}

1. Ingle JI (2002) Diagnostic acuity versus negligence. J Endod 28, 840-841.

2. Parirokh M, Mirsoltani B, Raoof M, Tabrizchi H, Haghdoost AA (2011) Comparative study of subcutaneous tissue responses to a novel root-end filling material and white and grey mineral trioxide aggregate. Int Endod J 44, 283-289.

3. Ozbas H, Yaltirik M, Bilgic B, Issever H (2003) Reactions of connective tissue to compomers, composite and amalgam root-end filling materials. Int Endod J 36, 281-287.

4. Zafalon EJ, Versiani MA, de Souza CJ, Moura CC, Dechichi $P$ (2007) In vivo comparison of the biocompatibility of two root canal sealers implanted into the subcutaneous connective tissue of rats. Oral Surg Oral Med Oral Pathol Oral Radiol Endod 103, e88-94.

5. Kaplan AE, Ormaechea MF, Picca M, Canzobre MC, Ubios AM (2003) Rheological properties and biocompatibility of endodontic sealers. Int Endod J 36, 527-532.

6. Bouillaguet S, Wataha JC, Lockwood PE, Galgano C, Golay A, Krejci I (2004) Cytotoxicity and sealing properties of four classes of endodontic sealers evaluated by succinic dehydrogenase activity and confocal laser scanning microscopy. Eur J Oral Sci 112, 182-187.

7. Bin CV, Valera MC, Camargo SE, Rabelo SB, Silva GO, Balducci I et al. (2012) Cytotoxicity and genotoxicity of root canal sealers based on mineral trioxide aggregate. J Endod 38, 495-500

8. Gomes-Filho JE, Bernabé PF, Nery MJ, Otoboni-Filho JA, Dezan-Júnior E, de Moraes Costa MM et al. (2008) Reaction of rat connective tissue to a new calcium hydroxide-based sealer. Oral Surg Oral Med Oral Pathol Oral Radiol Endod 106, e71-76.

9. Gomes-Filho JE, Watanabe S, Lodi CS, Cintra LT, Nery MJ, Filho JA et al. (2012) Rat tissue reaction to MTA FILLAPEX ${ }^{\circledR}$. Dent Traumatol 28, 452-456.

10. Marques NC, Lourenço Neto N, Fernandes AP, Rodini Cde O, Duarte MA, Oliveira TM (2013) Rat subcutaneous tissue response to MTA Fillapex ${ }^{\circledR}$ and Portland cement. Braz Dent J 24, 10-14.

11. Húngaro Duarte MA, de Oliveira El Kadre GD, Vivan RR, Guerreiro Tanomaru JM, Tanomaru Filho M, de Moraes IG (2009) Radiopacity of portland cement associated with different radiopacifying agents. J Endod 35, 737-740.

12. Saidon J, He J, Zhu Q, Safavi K, Spångberg LS (2003) Cell and tissue reactions to mineral trioxide aggregate and Portland cement. Oral Surg Oral Med Oral Pathol Oral Radiol Endod 95, 483-489.

13. Ribeiro DA, Duarte MAH, Matsumoto MA, Marques ME, Salvadori DM (2005) Biocompatibility in vitro tests of mineral trioxide aggregate and regular and white Portland cements. J Endod 31, 605-607.

14. Islam I, Chng HK, Yap AU (2006) Comparison of the physical and mechanical properties of MTA and portland cement. J Endod 32, 193-197.

15. Sakai VT, Moretti AB, Oliveira TM, Fornetti AP, Santos CF, 
Machado MA et al. (2009) Pulpotomy of human primary molars with MTA and Portland cement: a randomised controlled trial. Br Dent J 207, E5.

16. Oliveira TM, Moretti AB, Sakai VT, Lourenço Neto N, Santos CF, Machado MA et al. (2013) Clinical, radiographic and histologic analysis of the effects of pulp capping materials used in pulpotomies of human primary teeth. Eur Arch Paediatr Dent 14, 65-71.

17. Kim EC, Lee BC, Chang HS, Lee W, Hong CU, Min KS (2008) Evaluation of the radiopacity and cytotoxicity of Portland cements containing bismuth oxide. Oral Surg Oral Med Oral Pathol Oral Radiol Endod 105, e54-57.

18. Camilleri J, Cutajar A, Mallia B (2011) Hydration characteristics of zirconium oxide replaced Portland cement for use as a root-end filling material. Dent Mater 27, 845-854.

19. Cutajar A, Mallia B, Abela S, Camilleri J (2011) Replacement of radiopacifier in mineral trioxide aggregate; characterization and determination of physical properties. Dent Mater 27, 879-891.

20. Gomes Cornélio AL, Salles LP, Campos da Paz M, Cirelli JA, Guerreiro-Tanomaru JM, Tanomaru Filho M (2011) Cytotoxicity of Portland cement with different radiopacifying agents: a cell death study. J Endod 37, 203-210.

21. Hungaro Duarte MA, Minotti PG, Rodrigues CT, Zapata RO, Bramante CM, Tanomaru Filho M et al. (2012) Effect of different radiopacifying agents on the physicochemical properties of white Portland cement and white mineral trioxide aggregate. J Endod 38, 394-397.

22. Coutinho-Filho T, De-Deus G, Klein L, Manera G, Peixoto C, Gurgel-Filho ED (2008) Radiopacity and histological assessment of Portland cement plus bismuth oxide. Oral Surg Oral Med Oral Pathol Oral Radiol Endod 106, e69-77.
23. Al-Omari WM, Abu-Zaghlan MS, Hammad HM (2011) Reaction of rat connective tissue to Mineral Trioxide Aggregate and Diaket. BMC Oral Health 11, doi:10.1186/1472-6831-11-17.

24. Zmener O, Martinez Lalis R, Pameijer CH, Chaves C, Kokubu G, Grana D (2012) Reaction of rat subcutaneous connective tissue to a mineral trioxide aggregate-based and a zinc oxide and eugenol sealer. J Endod 38, 1233-1238.

25. Torabinejad M, Pitt Ford TR (1996) Root end filling materials: a review. Endod Dent Traumatol 12, 161-178.

26. Danesh G, Dammaschke T, Gerth HU, Zandbiglari T, Schäfer E (2006) A comparative study of selected properties of ProRoot mineral trioxide aggregate and two Portland cements. Int Endod J 39, 213-219.

27. Coomaraswamy KS, Lumley PJ, Hofmann MP (2007) Effect of bismuth oxide radiopacifier content on the material properties of an endodontic Portland cement-based (MTA-like) system. J Endod 33, 295-298.

28. Bortoluzzi EA, Guerreiro-Tanomaru JM, Tanomaru-Filho M, Duarte MA (2009) Radiographic effect of different radiopacifiers on a potential retrograde filling material. Oral Surg Oral Med Oral Pathol Oral Radiol Endod 108, 628-632.

29. American National Standards Institute / American Dental Association (2000) Endodontic sealing material. ANSI/ADA Standard No. 57, Chicago.

30. de Morais CA, Bernardineli N, Garcia RB, Duarte MA, Guerisoli DM (2006) Evaluation of tissue response to MTA and Portland cement with iodoform. Oral Surg Oral Med Oral Pathol Oral Radiol Endod 102, 417-421.

31. Guerreiro-Tanomaru JM, Cornélio AL, Andolfatto C, Salles LP, Tanomaru-Filho M (2012) pH and antimicrobial activity of Portland cement associated with different radiopacifying agents. ISRN Dent 2012:469019. 